\title{
Effects of Early Ulinastatin Injection Combined With Hyperbaric Oxygen on Myocardial Enzymes and Cognitive Function in Patients with Acute Moderate and Severe Carbon Monoxide Poisoning
}

\author{
RONG WANG* ${ }^{*}$ XIAOQING XIONG AND CHUNHU ZHAO
}

Department of Emergency, The Second Clinical Medical College, Yangtze University, No.72 Jingzhong road, Jingzhou 434020, Hubei, China

Wang et al.: Combined Effect of Ulinastatin Injection and Hyperbaric Oxygen in Carbon Monoxide Poisoning Patients

\begin{abstract}
To observe the effect of early ulinastatin injection combined with hyperbaric oxygen on myocardial enzyme and cognitive function in patients with acute moderate and severe carbon monoxide poisoning. From May 2017 December 2020, 104 patients with acute carbon monoxide poisoning coma were divided into groups according to their treatment plan, 52 cases in the control group were treated with hyperbaric oxygen. Ulastatin group 52 cases were treated with early ulastatin injection combined with hyperbaric oxygen. The curative effect and incidence of delayed encephalopathy were counted, the average recovery time of the two groups was recorded, the changes of Hasegawa dementia scale score and Mini mental state examination score were compared between the two groups and the differences of blood gas index, myocardial enzyme index, and oxidative stress index and blood viscosity were detected. Ulinastatin group had higher efficacy than the control group $(\mathbf{p}<\mathbf{0 . 0 5})$. The blood oxygen partial pressure and superoxide dismutase increased in ulinastatin group and control group. The blood carbon dioxide partial pressure, creatine kinase, creatine kinase isoenzyme, aspartate aminotransferase, lactate dehydrogenase and malondialdehyde, catalase, lipid peroxide decreased. The oxygen partial pressure, superoxide dismutase of ulinastatin group after treatment was higher than that of control group, carbon dioxide partial pressure, myocardial enzyme index and malondialdehyde, catalase, lipid peroxide were lower than those of control group $(\mathbf{p}<0.05)$. The whole blood (high and low cut) viscosity and plasma viscosity of ulinastatin group and control group decreased, the Hasegawa dementia scale score and Mini mental state examination score increased and the blood viscosity of ulinastatin group was lower than that of control group after treatment and the Hasegawa dementia scale score and Mini mental state examination score were higher than that of control group $(\mathbf{p}<\mathbf{0 . 0 5})$.Average recovery time of ulinastatin group was shorter than that of control group and the incidence of delayed encephalopathy was lower than that of control group $(\mathbf{p}<0.05)$. Early ulinastatin injection combined with hyperbaric oxygen in the treatment of acute carbon monoxide poisoning coma can reduce oxidative stress injury, reduce myocardial enzyme expression and blood viscosity, improve blood gas index, promote patients to wake up and reduce the occurrence of delayed encephalopathy. It is worthy of clinical recommendation.
\end{abstract}

Key words: Ulinastatin, hyperbaric oxygen, acute carbon monoxide poisoning, coma, delayed encephalopathy, curative effect

Carbon monoxide poisoning is a common disease of accidental life poisoning and acute occupational poisoning. It refers to the incomplete combustion of carbon containing substances to produce colorless, odorless and non-stimulation carbon monoxide. After inhalation through the respiratory tract, it combines with hemoglobin, so that hemoglobin loses its oxygen carrying capacity and role, thereby inducing different degrees of hypoxia performance, causing multiple organ lesions dominated by central nervous system function damage. Some patients with severe poisoning may even endanger life ${ }^{[1]}$. Relevant data ${ }^{[2]}$ show that China's

${ }^{*}$ Address for correspondence

E-mail:wr20050618@126.com 
carbon monoxide poisoning has a high disability rate and mortality rate, which is prone to occur in winter. Among them, occupational carbon monoxide poisoning is mostly collective poisoning and the mortality rate is high.

Hyperbaric oxygen therapy is currently the preferred treatment for carbon monoxide poisoning, but there are still some patients due to coma time is long or unable to wake up or wake up after epilepsy and dementia and other complications seriously affect the prognosis of patients. Ulinastatin, a protease inhibitor, can inhibit the activity of various proteolytic enzymes. It is now widely used in the treatment of acute pancreatitis clinic, but it can also be used for the rescue of acute circulatory failure $^{[3]}$. Therefore, this study observed the effect of early ulinastatin injection combined with hyperbaric oxygen on myocardial enzymes and cognitive function in patients with acute moderate and severe carbon monoxide poisoning, aiming to provide new ideas for the treatment of clinical carbon monoxide poisoning.

\section{MATERIALS AND METHODS}

\section{General information:}

Diagnostic criteria: Acute carbon monoxide poisoning meets the criteria in Practical internal science ${ }^{[4]}$ : Has a clear carbon monoxide contact history; patients with carbon monoxide poisoning symptoms; Abnormal carbon monoxide hemoglobin (HbCO) could be detected in arterial blood by chemical examination; Abnormal electroencephalogram (EEG) examination.

Severity-Mild: dizziness and headache, nausea and vomiting, palpitations, fatigue as the main performance, laboratory tests showed that $\mathrm{HbCO}<30 \%$; Moderate: covering the main manifestations of mild and accompanied by heart rate and respiratory acceleration, mucosal cherry red, blurred consciousness or shallow coma, etc., Laboratory examination showed that $30 \%$ $\leq \mathrm{HbCO}<50 \%$; Severe: the main manifestations were deep coma, limb muscle relaxation and even convulsion and the test showed that $\mathrm{HbCO}>50 \%$.

Case selection criteria: Inclusion criteria-Acute moderate and severe carbon monoxide poisoning standards; age $\geq 18$ y old, male and female; admission within $6 \mathrm{~h}$ of poisoning; Glasgow coma score (GCS) $<7$; Complete case data. Exclusion criteria-coma patients caused by stress shock, intracranial hemorrhage and other reasons; Hyperbaric oxygen contraindication; with hemorrhagic diseases; Allergic constitution; Pregnant or lactating women.
Medical records: 104 cases of coma patients with acute carbon monoxide poisoning admitted to our hospital from May 2017 to December 2020 were selected and divided into groups according to their treatment plans, 52 cases in the control group were treated with hyperbaric oxygen, 18 males and 34 females; aged 18-65 y old, with an average of $(43.36 \pm 12.08)$ y old; the course of disease was $0.5 \mathrm{~h}-6 \mathrm{~h}$, with an average of $(3.25 \pm 1.17) \mathrm{h}$; 19 cases were moderate, 33 cases were severe; GCS score was $(11.36 \pm 1.41)$ points. In the ulinastatin group, 52 cases were treated with early ulinastatin injection combined with hyperbaric oxygen therapy, 29 males and 23 females; aged 20-66 y old, with an average of $(42.71 \pm 10.84) \mathrm{y}$ old; the course of disease was $0.5 \mathrm{~h}-6 \mathrm{~h}$, with an average of $(3.16 \pm 1.25) \mathrm{h}$; Moderate 22 cases, severe 30 cases; GCS score was $(11.29 \pm 1.45)$. The general data of the two groups were relatively balanced and the test could be carried out $(p>0.05)$.

\section{Method:}

All patients were given face mask oxygen inhalation, $10 \mathrm{mg}$ dexamethasone $+125 \mathrm{ml}$ mannitol $+250 \mathrm{ml}$ saline intravenous injection; Patients in the control group were given hyperbaric oxygen therapy: patients were placed in a multi-person or single-person pure oxygen chamber (2 atmospheric pressure), $90 \mathrm{~min} /$ time, divided into 2 times, $80 \mathrm{~min}$ oxygen inhalation, $10 \mathrm{~min}$ air inhalation and then 25 min decompression out of the warehouse once a day, 10 times per course of treatment.

The ulinastatin group was treated with early ulinastatin injection on the basis of hyperbaric oxygen therapy in the control group. The ulinastatin was produced by intravenous injection of $300000 \mathrm{U}$ Guangdong Tianpu Biochemical Pharmaceutical Co., Ltd., H19990133, continuous administration for $1 \mathrm{w}$, three times a d.

\section{Efficacy criteria:}

Referring to the evaluation of "Practical internal science" ${ }^{, 4]}$. Effectiveness: The patient's consciousness fully recovered within $12 \mathrm{~h}$, after the end of treatment, myocardial function, sensory, intellectual recovery, dizziness, headache, nausea and vomiting, palpitations, fatigue and other clinical symptoms disappeared, life can take care of itself; Effective: Patients recovered consciousness within $36 \mathrm{~h}$ after treatment, myocardial function, sensory, intellectual and other mild abnormalities, clinical symptoms reduced; Invalid: The above standards were not met.

\section{Detection method:}

Special Issue 3, 2021 
All patients in $10 \mathrm{~d}$ after treatment to take fasting venous blood $3 \mathrm{ml}$, centrifuge $10 \mathrm{~min}(3000 \mathrm{r} / \mathrm{min})$, separation of serum preparation; superoxide dismutase (SOD), malondialdehyde (MDA), catalase (CAT) and lipid peroxide (LPO) were detected by immunoturbidimetry; Myocardial enzyme indicators creatine kinase (CK), creatine kinase isoenzyme (CK-MB), aspartate aminotransferase (AST), lactate dehydrogenase (LDH) enzyme-linked immunosorbent assay (ELISA); Arterial blood $\mathrm{PaO}_{2}, \mathrm{PaCO}_{2}$ levels were detected by blood gas analyzer.

\section{Score standard:}

The application of Hasegawa Dementia Scale (HDS) score covers orientation, memory function, common sense, object memorization naming memory, calculation, etc. The score is proportional to cognitive function. Illiteracy $<16$, secondary school or above $<24$, primary school $<20$ points with cognitive impairment ${ }^{[5-7]}$.

Mini mental state examination (MMSE) score covers calculation, memory, memory, orientation, language and other aspects, the score is proportional to cognitive function. Illiteracy $\leq 17$ points; Primary school $\leq 20$; Those with secondary school or above $\leq 24$ are divided into cognitive dysfunction.

\section{Statistical method:}

The data were processed by Statistical Package for the Social Sciences (SPSS) 19.0. The measurement indexes were described by $(\overline{\mathrm{x}} \pm \mathrm{s})$. The $\mathrm{t}$ test was used for comparison. The enumeration data were described by the number of cases (percentage). The $\chi^{2}$ test was used for comparison. The test level was 0.05 .

\section{RESULTS AND DISCUSSION}

TABLE 1: CLINICAL ANALYSIS OF TWO GROUPS

\begin{tabular}{lccccc}
\hline Group & $\begin{array}{c}\text { Number } \\
\text { of cases }\end{array}$ & $\begin{array}{c}\text { Effect (Number of } \\
\text { cases) }\end{array}$ & $\begin{array}{c}\text { Effective (Number of } \\
\text { cases) }\end{array}$ & $\begin{array}{c}\text { Invalid (Number of } \\
\text { cases) }\end{array}$ & $\begin{array}{c}\text { Total efficiency [n } \\
\text { (\%)] }\end{array}$ \\
\hline $\begin{array}{l}\text { Control group } \\
\text { Observation }\end{array}$ & 52 & 21 & 18 & 13 & $39(75.00)$ \\
Group & 52 & 33 & 15 & 4 & $48(92.31)^{\#}$ \\
\hline
\end{tabular}

Note: Comparison with control group, ${ }^{\#} \mathrm{p}<0.05$

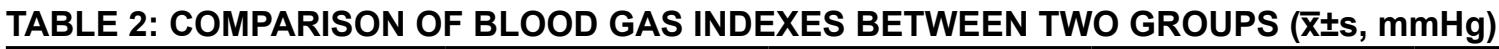

\begin{tabular}{lccccc}
\hline \multirow{2}{*}{ Group } & \multirow{2}{*}{\begin{tabular}{c} 
Number \\
\cline { 3 - 6 }
\end{tabular}} & \multicolumn{2}{c}{$\mathrm{PaO}_{2}$} & \multicolumn{2}{c}{$\mathrm{PaCO}_{2}$} \\
\hline of cases & Before treatment & After treatment & Before treatment & After treatment \\
Observation Group & 52 & $52.26 \pm 10.14$ & $81.36 \pm 5.68^{*}$ & $56.36 \pm 5.98$ & $44.74 \pm 4.89^{*}$ \\
\hline
\end{tabular}

Note: Comparison before treatment, ${ }^{*} p<0.05$; Comparison with control group, ${ }^{*} p<0.05$ 
www.ijpsonline.com

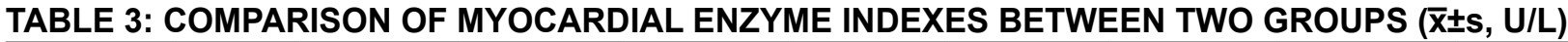

\begin{tabular}{|c|c|c|c|c|c|c|c|c|c|}
\hline \multirow[b]{2}{*}{ Group } & \multirow{2}{*}{$\begin{array}{l}\text { Number } \\
\text { of cases }\end{array}$} & \multicolumn{2}{|c|}{ CK } & \multicolumn{2}{|c|}{ CK-MB } & \multicolumn{2}{|c|}{ AST } & \multicolumn{2}{|c|}{ LDH } \\
\hline & & $\begin{array}{c}\text { Before } \\
\text { treatment }\end{array}$ & $\begin{array}{c}\text { After } \\
\text { treatment }\end{array}$ & $\begin{array}{c}\text { Before } \\
\text { treatment }\end{array}$ & $\begin{array}{c}\text { After } \\
\text { treatment }\end{array}$ & $\begin{array}{c}\text { Before } \\
\text { treatment }\end{array}$ & $\begin{array}{c}\text { After } \\
\text { treatment }\end{array}$ & $\begin{array}{c}\text { Before } \\
\text { treatment }\end{array}$ & $\begin{array}{c}\text { After } \\
\text { treatment }\end{array}$ \\
\hline $\begin{array}{l}\text { Control } \\
\text { group }\end{array}$ & 52 & $\begin{array}{l}1125.63 \\
\pm 214.85\end{array}$ & $\begin{array}{c}175.36 \\
\pm 52.33^{*}\end{array}$ & $\begin{array}{c}55.89 \\
\pm 13.23\end{array}$ & $\begin{array}{c}15.89 \\
\pm 3.64^{*}\end{array}$ & $\begin{array}{c}82.33 \\
\pm 25.36\end{array}$ & $\begin{array}{c}35.63 \\
\pm 12.04^{*}\end{array}$ & $\begin{array}{l}465.36 \\
\pm 72.25\end{array}$ & $\begin{array}{c}255.36 \\
\pm 37.58^{*}\end{array}$ \\
\hline $\begin{array}{l}\text { Observation } \\
\text { Group }\end{array}$ & 52 & $\begin{array}{l}1098.52 \\
\pm 237.56 \\
\end{array}$ & $\begin{array}{c}102.58 \\
\pm 24.13^{* \#} \\
\end{array}$ & $\begin{array}{c}56.05 \\
\pm 12.42 \\
\end{array}$ & $\begin{array}{c}12.04 \\
\pm 3.13^{* \#} \\
\end{array}$ & $\begin{array}{c}80.14 \\
\pm 23.94 \\
\end{array}$ & $\begin{array}{c}25.85 \\
\pm 6.87^{* \#} \\
\end{array}$ & $\begin{array}{l}471.05 \\
\pm 68.32 \\
\end{array}$ & $\begin{array}{c}204.03 \\
\pm 26.81^{* \#}\end{array}$ \\
\hline
\end{tabular}

Note: Comparison before treatment, ${ }^{*} \mathrm{p}<0.05$; Comparison with control group, ${ }^{*} \mathrm{p}<0.05$

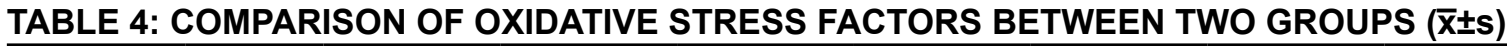

\begin{tabular}{|c|c|c|c|c|c|c|c|c|c|}
\hline \multirow[b]{2}{*}{ Group } & \multirow{2}{*}{$\begin{array}{l}\text { Number } \\
\text { of cases }\end{array}$} & \multicolumn{2}{|c|}{ SOD (mU/L) } & \multicolumn{2}{|c|}{ MDA ( $\mu \mathrm{mol} / \mathrm{L})$} & \multicolumn{2}{|c|}{ CAT ( $\mu \mathrm{mol} / \mathrm{L})$} & \multicolumn{2}{|c|}{ LPO ( $\mu \mathrm{mol} / \mathrm{L})$} \\
\hline & & $\begin{array}{c}\text { Before } \\
\text { treatment }\end{array}$ & $\begin{array}{c}\text { After } \\
\text { treatment }\end{array}$ & $\begin{array}{c}\text { Before } \\
\text { treatment }\end{array}$ & $\begin{array}{c}\text { After } \\
\text { treatment }\end{array}$ & $\begin{array}{c}\text { Before } \\
\text { treatment }\end{array}$ & $\begin{array}{c}\text { After } \\
\text { treatment }\end{array}$ & $\begin{array}{c}\text { Before } \\
\text { treatment }\end{array}$ & $\begin{array}{c}\text { After } \\
\text { treatment }\end{array}$ \\
\hline $\begin{array}{l}\text { Control } \\
\text { group }\end{array}$ & 52 & $\begin{array}{c}61.25 \\
\pm 12.05\end{array}$ & $\begin{array}{c}78.22 \\
\pm 10.74^{*}\end{array}$ & $\begin{array}{c}9.25 \\
\pm 1.57\end{array}$ & $\begin{array}{c}6.85 \\
\pm 1.23^{*}\end{array}$ & $\begin{array}{l}251.36 \\
\pm 42.56\end{array}$ & $\begin{array}{c}145.25 \\
\pm 31.26^{*}\end{array}$ & $\begin{array}{c}8.25 \\
\pm 1.46\end{array}$ & $\begin{array}{c}6.12 \\
\pm 0.97^{*}\end{array}$ \\
\hline $\begin{array}{l}\text { Observation } \\
\text { Group }\end{array}$ & 52 & $\begin{array}{c}62.36 \\
\pm 10.71\end{array}$ & $\begin{array}{c}89.36 \\
\pm 8.74^{* \#}\end{array}$ & $\begin{array}{c}9.05 \\
\pm 1.73\end{array}$ & $\begin{array}{c}5.41 \\
\pm 1.07^{* \#}\end{array}$ & $\begin{array}{l}247.12 \\
\pm 51.92\end{array}$ & $\begin{array}{c}105.14 \\
\pm 28.66^{* \#}\end{array}$ & $\begin{array}{r}8.30 \\
\pm 1.41\end{array}$ & $\begin{array}{c}5.03 \\
\pm 0.81^{* \#}\end{array}$ \\
\hline
\end{tabular}

Note: Comparison before treatment, ${ }^{*} \mathrm{p}<0.05$; Comparison with control group, ${ }^{\sharp} \mathrm{p}<0.05$

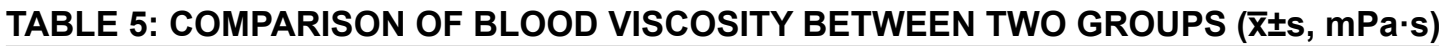

\begin{tabular}{|c|c|c|c|c|c|c|c|}
\hline \multirow{3}{*}{ Group } & \multirow{3}{*}{$\begin{array}{l}\text { Number } \\
\text { of cases }\end{array}$} & \multicolumn{4}{|c|}{ Whole blood viscosity } & \multirow{2}{*}{\multicolumn{2}{|c|}{ Plasma viscosity }} \\
\hline & & \multicolumn{2}{|c|}{ High cut } & \multicolumn{2}{|c|}{ Low cut } & & \\
\hline & & $\begin{array}{c}\text { Before } \\
\text { treatment }\end{array}$ & $\begin{array}{c}\text { After } \\
\text { treatment }\end{array}$ & $\begin{array}{c}\text { Before } \\
\text { treatment }\end{array}$ & $\begin{array}{c}\text { After } \\
\text { treatment }\end{array}$ & $\begin{array}{c}\text { Before } \\
\text { treatment }\end{array}$ & $\begin{array}{c}\text { After } \\
\text { treatment }\end{array}$ \\
\hline Control group & 52 & $4.65 \pm 0.58$ & $4.18 \pm 0.43^{*}$ & $10.56 \pm 2.12$ & $9.12 \pm 1.86^{*}$ & $1.56 \pm 0.33$ & $1.42 \pm 0.26^{*}$ \\
\hline $\begin{array}{l}\text { Observation } \\
\text { Group }\end{array}$ & 52 & $4.61 \pm 0.63$ & $3.37 \pm 0.38^{* \#}$ & $10.47 \pm 2.08$ & $8.27 \pm 1.74^{* \#}$ & $1.58 \pm 0.35$ & $1.23 \pm 0.21^{* \#}$ \\
\hline
\end{tabular}

Note: Comparison before treatment, ${ }^{*} \mathrm{p}<0.05$; Comparison with control group, ${ }^{\#} \mathrm{p}<0.05$

TABLE 6: COMPARISON OF HDS SCORES AND MMSE SCORES BETWEEN THE TWO GROUPS ( $\bar{X} \pm s$, Subdivision)

\begin{tabular}{lccccc}
\hline \multirow{2}{*}{ Group } & Number & \multicolumn{2}{c}{ HDS Score } & \multicolumn{2}{c}{ MMSE Score } \\
\cline { 3 - 6 } & of cases & Before treatment & After treatment & Before treatment & After treatment \\
\hline Control group & 52 & $9.85 \pm 2.98$ & $17.89 \pm 4.11^{*}$ & $20.15 \pm 3.23$ & $24.25 \pm 2.59^{*}$ \\
$\begin{array}{l}\text { Observation } \\
\text { Group }\end{array}$ & 52 & $9.78 \pm 3.05$ & $23.97 \pm 4.56^{* \#}$ & $20.23 \pm 3.08$ & $26.45 \pm 3.02^{* \#}$ \\
\hline
\end{tabular}

Note: Comparison before treatment, ${ }^{*} \mathrm{p}<0.05$; Comparison with control group, ${ }^{\#} \mathrm{p}<0.05$

Table 7.

Carbon monoxide poisoning is mainly caused by patients exposed to carbon monoxide environment. Excessive inhalation of carbon monoxide leads to poisoning mainly due to accidental poisoning caused by incorrect use of heating stoves in home life, gas pool leakage and poor ventilation in the room. It also includes coal mine gas explosion in the production process, maintenance of coal-fired boiler exhaust system equipment is not in accordance with the operation specification, and some patients are suicidal behavior leading to carbon monoxide poisoning ${ }^{[8]}$. At present, clinical carbon monoxide poisoning can be classified as mild, moderate and severe poisoning, among which moderate and severe patients can show dyspnea, disturbance of consciousness and even deep coma. If the treatment is not timely, complications such as brain edema and shock can occur and the mortality is relatively high ${ }^{[9-10]}$. Therefore, effective treatment for moderate and severe carbon monoxide is particularly critical to improve the prognosis of patients.

Hyperbaric oxygen therapy is a physical therapy that places patients in a pressurized cabin, inhales high concentration oxygen or pure oxygen in a high pressure environment beyond atmospheric pressure and improves the oxygen content of blood to improve the disease. It is a standard method for clinical treatment of carbon monoxide. However, the latest research suggests that other treatments should be supplemented for patients with moderate and severe carbon monoxide poisoning to more effectively improve the efficacy ${ }^{[11-13]}$. Ulinastatin, a protease inhibitor, can inhibit neutrophil elastase, serine protease ( trypsin, $\alpha$-chymotrypsin ) and hyaluronidase and other enzymes, thereby improving 
TABLE 7: COMPARISON OF AVERAGE RECOVERY TIMEAND INCIDENCE OF DELAYED ENCEPHALOPATHY BETWEEN THE TWO GROUPS

\begin{tabular}{lccc}
\hline Group & Number of cases & Average recovery time $(\overline{\mathrm{x}} \pm \mathrm{s}, \mathrm{h})$ & Incidence of delayed encephalopathy [n (\%)] \\
\hline Control group & 52 & $26.32 \pm 6.14$ & $7(13.46)$ \\
Observation Group & 52 & $18.55 \pm 4.23^{\#}$ & $1(1.92)^{\#}$ \\
\hline
\end{tabular}

Note: Comparison with control group, ${ }^{*} \mathrm{p}<0.05$

the body's circulation disorder ${ }^{[14-16]}$. The results showed that the curative effect of ulinastatin group was significantly higher than that of control group and $\mathrm{PaO}_{2}$ of ulinastatin group was higher than that of control group, $\mathrm{PaCO}_{2}$ was lower than that of control group. Hyperbaric oxygen therapy can improve the sum of oxygen dissolution coefficient and dispersion rate of blood oxygen in tissues, so that blood can obtain more sufficient oxygen, promote cell regeneration and capillary production, improve the hypoxia state of tissues, and effectively eliminate edema and microcirculation disturbance. On this basis, ulinastatin can stabilize the lysosomal membrane, inhibit the production of myocardial inhibitory factors, stabilize the lysosomal membrane and play a synergistic effect with hyperbaric oxygen therapy in stabilizing and restoring circulatory function and cardiac function, so as to further improve the clinical efficacy.

Further analysis of related indicators showed that the myocardial enzyme indexes CK, CK-MB, AST, LDH and blood viscosity of ulinastatin group after treatment were lower than those of control group and the improvement of oxidative stress response factor after treatment was better than that of control group. Oxygen therapy can effectively correct the hypoxic state of brain injury area, improve blood oxygen dispersion distance, contract blood vessels and improve blood flow velocity, reduce blood viscosity, effectively repair and remove necrotic tissue, regeneration of capillaries and collagen fibers. In addition, hyperbaric oxygen therapy can improve endothelial cell function and macrophage phagocytosis by improving blood-spinal cord barrier to reduce the level of inflammation and improve oxidative stress in the body ${ }^{[17]}$. Ulinastatin can inhibit the secretion of myocardial inhibitory factor, stabilize the lysosomal membrane, inhibit the release of lysosomal enzyme and thus play a role in scavenging oxygen free radicals and inhibiting the release of inflammatory mediators. Therefore, combined hyperbaric oxygen therapy can further improve the curative effect in improving cardiac function, oxidative stress response and blood viscosity.

Further study found that HDS score and MMSE score after treatment were higher than those in the control group, the average recovery time in ulinastatin group was shorter than that in the control group and the incidence of delayed encephalopathy was lower than that in the control group. The above results suggested that early ulinastatin injection combined with hyperbaric oxygen in the treatment of acute carbon monoxide poisoning could further improve the cognitive function of patients and promote the recovery of coma patients. Hyperbaric oxygen therapy can promote the expression of specific phosphoprotein in nerve tissue, thereby promoting the growth, regeneration, development and synaptic reconstruction of neurons and helping to restore the nerve function and cognitive function of the body. In addition, nerve tissue specific phosphate protein can also promote the recovery of sensory function and motor function, thereby shortening the recovery time of coma patients ${ }^{[18]}$. Literatures ${ }^{[19-20]}$ suggest that ulinastatin can improve immune dysfunction, abnormal protein metabolism and renal function caused by related stimuli, thereby improving the body's circulatory state and minimizing cell damage caused by external stimuli, so as to promote recovery and improve body related functions.

In summary, early ulinastatin injection combined with hyperbaric oxygen in the treatment of coma caused by acute carbon monoxide poisoning can reduce oxidative stress injury, reduce the expression of myocardial enzymes and blood viscosity, improve blood gas indexes, promote the recovery of patients and reduce the occurrence of delayed encephalopathy, which is worthy of clinical application.

\section{Conflict of interests:}

The authors declared no conflicts of interest.

\section{REFERENCES}

1. Meng F, Du C, Zhang Y, Wang S, Zhou Q, Wu L, et al. Protective effect of rhubarb combined with ulinastatin for patients with sepsis. Medicine 2020;99(7):18895.

2. Liao SC, Mao YC, Yang KJ, Wang KC, Wu LY, Yang CC. Targeting optimal time for hyperbaric oxygen therapy following carbon monoxide poisoning for prevention of delayed neuropsychiatric sequelae: A retrospective study. J Neurol Sci 2019;396:187-92.

3. Zhao Y, Cai H, Zhou P, Lin S, Pan Y, Liang X. Protective effect of ulinastatin on hepatic ischemia reperfusion injury through autophagy activation in Chang liver cells. J Cell Biochem 2019;120(9):14960-70. 
4. Yang CC, Chuang YF, Chen PE, Tao P, Tung TH, Chien $\mathrm{CW}$. The occurrence of delayed neuropsychologic sequelae in acute carbon monoxide poisoning patients after treatment with hyperbaric or normobaric oxygen therapy. Medicine 2021;100(2):24183.

5. Zhou X, Tang G, Li J. Some questions on the use of Xuebijing combined with Ulinastatin in treating patients with sepsis. Am J Emerg Med 2017;35(6):925-6.

6. Gu J, Zeng J, Wang X, Gu X, Zhang X, Zhang P, et al. LRCH1 polymorphisms linked to delayed encephalopathy after acute carbon monoxide poisoning identified by GWAS analysis followed by Sequenom MassARRAY ${ }^{\circledR}$ validation. BMC Med Genet 2019;20(1):1-8.

7. QiAL, Wu Y, Dong N, Chai YF, Zhu XM, Yao YM. Recombinant human ulinastatin improves immune dysfunction of dendritic cells in septic mice by inhibiting endoplasmic reticulum stressrelated apoptosis. Int Immunopharmacol 2020;85(13):106643.

8. Agarwal A, Garg D, Goyal V, Vy V, Singh MB, Srivastava MP. Acute encephalopathy followed by delayed myelopathy: A rare presentation of organophosphate poisoning. Trop Doct 2020;50(2):162-4.

9. Yao YT, Fang NX, Liu DH, Li LH. Ulinastatin reduces postoperative bleeding and red blood cell transfusion in patients undergoing cardiac surgery: A PRISMA-compliant systematic review and meta-analysis. Medicine 2020;99(7):19184.

10. Ju M, He H, Chen S, Liu Y, Liu Y, Pan S, et al. Ulinastatin ameliorates LPS-induced pulmonary inflammation and injury by blocking the MAPK/NF- $\kappa$ B signaling pathways in rats. Mol Med Rep 2019;20(4):3347-54.

11. Nakajima M, Aso S, Matsui H, Kaszynski RH, Fushimi K, Yamaguchi $\mathrm{Y}$, et al. Prevalence of myocardial injury requiring percutaneous coronary intervention after acute carbon monoxide poisoning. Eur J Emerg Med 2020;27(3):213-6.

12. Yao JH, Li WM. Efficacy of ulinastatin for the treatment of patients with severe acute pancreatitis. Medicine 2019;98(43):17644.

13. Mijajlovic MD, Aleksic V, Milosevic N, Bornstein NM. Hyperbaric oxygen therapy in acute stroke: is it time for
Justitia to open her eyes?. Neurol Sci 2020;41(6):1381-90.

14. Ling L, Li Y, Li H, Li W, Zhang HB. MMP-2 and MMP-9 gene polymorphisms act as biological indicators for ulinastatin efficacy in patients with severe acute pancreatitis. Medicine 2019;98(24):121-7.

15. Baeza M, Muñoz-Ortega A, Vela N. Prevalence of acute poisoning treated in 3 hospitals in Southeast Spain. Rev Clin Esp 2020;220(4):236-43.

16. Meng C, Qian Y, Zhang WH, Liu Y, Song XC, Liu H, et al. A retrospective study of ulinastatin for the treatment of severe sepsis. Medicine 2020;99(49):23361.

17. Semple AB, Parry WH, Phillips DE. Acute copper poisoning. An outbreak traced to contaminated water from a corroded geyser. Lancet 1960;2(7152):700-1.

18. Zhai Y, Gan L, Huang S, Xing Q, Zhou X, Wang L, et al. Therapeutic effect of ultrasound interventional perirenal catheter-assisted early peripancreatic lavage of protease inhibitor on severe acute pancreatitis in miniature pigs. Pancreatology 2019;19(1):158-62.

19. Cao ZX, Song YQ, Bai WJ, Wang WJ, Zhao Y, Zhang SL, et al. Neutrophil-lymphocyte ratio as an early predictor for patients with acute paraquat poisoning: A retrospective analysis. Medicine 2019;98(37):17199.

20. Wu J, Yan X, Jin G. Ulinastatin protects rats from sepsisinduced acute lung injury by suppressing the JAK-STAT3 pathway. J Cell Biochem 2019;120(2):2554-9.

This is an open access article distributed under the terms of the Creative Commons Attribution-NonCommercial-ShareAlike 3.0 License, which allows others to remix, tweak, and build upon the work non-commercially, as long as the author is credited and the new creations are licensed under the identical terms

This article was originally published in a special issue, "Evolutionary Strategies in Biomedical Research and Pharmaceutical Sciences" Indian J Pharm Sci 2021:83(3) Spl issue;168-173 